\title{
DETECTION OF PROTEINS SYNTHESIZED IN THE CAP CELLS OF COPRINUS CINEREUS
}

\author{
TOSAKU KANDA, ISAO UNO, AND TATSUO ISHIKAWA \\ Institute of Applied Microbiology, University of Tokyo, \\ Bunkyo-ku, Tokyo 113, Japan
}

(Received June 20, 1986)

\begin{abstract}
Four proteins with molecular weights of 74,000, 72,000, 70,000, and 68,000 were readily detected by gel electrophoresis in the cap cells of the mature fruit bodies of Coprinus cinereus. But they were barely detectable in the stipe cells. The cap proteins were purified together and had a similar isoelectric point at around 8.0. They were all glycoproteins, and peptide mapping indicated that they shared common polypeptides. As measured by the immunoblotting method using antisera against them, these proteins were abundant in cap cells but extremely rare in stipe cells, in the primordia of fruit bodies, and in the mycelia of monokaryotic $\mathrm{Fis}^{\mathrm{cl}}$ and dikaryotic strains.
\end{abstract}

The mushroom Coprinus cinereus has been used extensively in developmental studies including depression of the enzyme synthesis related to a specific developmental process. Biochemical analysis of this fungus has revealed several enzymes which are synthesized during morphogenesis(1). For example, NADPdependent glutamate dehydrogenase in $C$. cinereus occurs at high specific activity in cap cells of fruit bodies, but is barely detectable in the stipe cells (2-5). In cap cells, the production of this enzyme is initiated at the early stage of meiosis (6). After the completion of meiosis, chitinase and some glucanases were produced only in cap cells (6). Many other enzymes were found in both the caps and stipes of fruit bodies (1). Histochemical observation demonstrated that in C. kimurae, several enzymes such as succinic dehydrogenase and cytochrome oxidase are distributed at the top part of stipes and in the margin of caps (7). Thus, comparisons of caps and stipes may reveal the regulatory patterns operating during morphogenesis of fruit bodies.

Polyacrylamide gel electrophoresis and immunochemical techniques are efficient methods for analyzing cellular proteins independent of enzymatic activities. Specific proteins are identified by electrophoresis, and antisera against these

Address reprint requests to: Dr. T. Ishikawa, Institute of Applied Microbiology, University of Tokyo, Bunkyo-ku, Tokyo 113, Japan. 
proteins are prepared and used to detect the presence of these proteins in various cells and tissues. The present paper describes the detection by electrophoretic and immunoblotting methods of four proteins distributed mainly in cap cells of fruit bodies formed in C. cinereus.

\section{MATERIALS AND METHODS}

Strains. A monokaryotic strain Fis ${ }^{\mathrm{cl}}$ A8B7 of Coprinus cinereus which forms monokaryotic fruit bodies was mainly used in this study. The origin and characteristics of $\mathrm{Fis}^{\mathrm{cl}}$ were described previously $(8,9)$. Dikaryons were obtained by inoculating ade-2 $A 2 B 2$ and ade- $2 f A 7 B 7$ on a slant medium.

Cultivation. All cultures were grown on malt-yeast medium(8). A piece of mycelium was inoculated on slants in test tubes $(18 \times 180 \mathrm{~cm})$, and incubated at $30^{\circ} \mathrm{C}$ under $12 \mathrm{hr}$ light $-12 \mathrm{hr}$ dark. Young primordia of fruit bodies were formed on the 6th day after inoculation, and the primordia of fruit bodies were observed at the 8 th day under the stated conditions. Fruit bodies of similar size were harvested at the time indicated and dissected into two parts, cap and stipe. Mycelia were grown on a cellophane sheet placed on solid malt-yeast medium in a petri dish.

Preparation of cell free extracts. Mycelia, primordia, stipes and caps were suspended in TEMP buffer consisting of $10 \mathrm{~mm}$ Tris- $\mathrm{HCl}$ buffer (pH 7.8), $1 \mathrm{~mm}$ EDTA, $1 \mathrm{~mm}$ 2-mercaptoethanol and $0.1 \mathrm{~mm}$ phenylmethylsulfonyl fluoride (Sigma Chem. Co.), then homogenized with a Waring blender for 2 min. The resulting homogenate was further homogenized in an Aminco French pressure cell (J5-598A) at $20,000 \mathrm{psi}$ and centrifuged at $20,000 \times g$ for $20 \mathrm{~min}$. The supernatants were used as crude extracts. These extracts were saturated with $\left(\mathrm{NH}_{4}\right)_{2} \mathrm{SO}_{4}$, and after $2 \mathrm{hr}$, centrifuged at $20,000 \times g$ for $20 \mathrm{~min}$. The precipitates were suspended in TEMP buffer, dialyzed and centrifuged at $20,000 \times g$ for $20 \mathrm{~min}$. The supernatant fractions were further concentrated by ultrafiltration with Immersible CX-10 (Millipore) and the resulting fluids were used as concentrated supernatant fractions.

DEAE-Sephacel and CM-Sepharose chromatography. Crude extracts were centrifuged at $105,000 \times g$ for $1 \mathrm{hr}$ and the supernatant fluid was applied to a DEAE-Sephacel column $(1.6 \times 15 \mathrm{~cm})$ connected directly with a CM-Sepharose CL$6 \mathrm{~B}$ column $(1.6 \times 15 \mathrm{~cm})$ which had been equilibrated with TEMP buffer. After the columns were washed with TEMP buffer (about $160 \mathrm{ml}$ ), the DEAE-Sephacel column was removed, and proteins were eluted from the CM-Sepharose CL-6B column with a linear gradient $(0-0.5 \mathrm{M})$ of $\mathrm{NaCl}$ in a total volume of $300 \mathrm{ml}$.

Gel electrophoresis. Sodium dodecyl sulfate-polyacrylamide gel electrophoresis (SDS-PAGE) was performed by the method of LAEMmLi(10). Protein samples were mixed with a half volume of a SDS-containing stop solution consisting of $9 \%$ SDS, $30 \mathrm{~mm}$ Tris- $\mathrm{HCl}(\mathrm{pH} 7.0), 6 \%$ mercaptoethanol, 3 mm EDTA and $15 \%$ glycerol, heated at $100{ }^{\circ} \mathrm{C}$ for $2 \mathrm{~min}$, and subjected to SDS-PAGE. The slab gels were stained for proteins with $0.1 \%$ Coomassie brilliant blue R250. The molecular weights of the proteins were calculated using the molecular weight 
markers (Pharmacia) as standard.

Peptide mapping. Peptide mapping was performed by the method of Cleveland et al. (11). A protein sample was applied to SDS-polyacrylamide gel in the presence of $0.05 \mu \mathrm{g}$ of Staphylococcus aureus V8 protease (Miles Laboratories). The gel was stained by the silver-staining method using the Daiichi kit (Daiichi Chem. Co.).

Periodic acid-Schiff staining. PAS staining was performed as described by Konat et al. (12).

Con A-peroxidase staining. Protein samples separated by SDS-PAGE were transferred onto nitrocellulose sheets (Toyo Roshi, Type TM-2) by the method of Howe and Hershey (13). Glycoproteins on the blotted nitrocellulose sheets were detected by the method of KiJimoto-Ochial et al. (14) with the following modification. The blotted sheets were first incubated with buffer A consisting of $10 \mathrm{~mm}$ Tris- $\mathrm{HCl}(\mathrm{pH} \mathrm{7.4)}, 0.9 \% \mathrm{NaCl}$ and $0.05 \%$ Tween 20 for $1 \mathrm{hr}$, and then with $1 \%$ peroxidase-Con A solution (Hohnen Oil Co.) in buffer B consisting of $10 \mathrm{~mm}$ Tris$\mathrm{HCl}, 1 \mathrm{mM} \mathrm{CaCl}_{2}, 1 \mathrm{mM} \mathrm{MnCl}_{2}$ and $0.9 \% \mathrm{NaCl}$ for $1 \mathrm{hr}$. The sheets were washed in buffer A with four changes during $1 \mathrm{hr}$ and then in $15 \mathrm{~mm}$ sodium phosphate buffer ( $\mathrm{pH}$ 6.8) with two changes during $1 \mathrm{hr}$. They were incubated with a development solution containing $50 \mathrm{ml}$ of sodium phosphate buffer ( $\mathrm{pH} \mathrm{6.8),} 30 \mu \mathrm{l}$ of $30 \% \mathrm{H}_{2} \mathrm{O}_{2}$ and $10 \mathrm{ml}$ of $3 \mathrm{mg} / \mathrm{ml}$ 4-chloro-1-naphthol in methanol. The enzymatic reaction was stopped by washing with excess water.

Antibody production. Antibodies were induced in a rabbit by an initial lymph node injection of about $200 \mu \mathrm{g}$ of antigen (a sample of purified cap proteins) in complete Freund adjuvant, followed by multiple intradermal injections of 200 to $400 \mu \mathrm{g}$ of antigen in complete Freund adjuvant at every additional 2 weeks (three times). The rabbit was bled 2 weeks after the last injection.

Immunoblotting. Protein samples separated by SDS-PAGE were transferred onto nitrocellulose sheets, and the presence of specific proteins was identified by treating the blotted sheets with specific antibody as described by HowE and Hershey (13). The blotted sheets were incubated with buffer $\mathrm{G}$ consisting of $1 \%$ gelatin, $0.9 \% \mathrm{NaCl}$ and $10 \mathrm{~mm}$ Tris- $\mathrm{HCl}(\mathrm{pH} \mathrm{7.4)}$ at room temperature for $1 \mathrm{hr}$, and then with antibody solution containing $0.1 \%$ anti-cap protein serum in buffer $\mathrm{G}$ at $4{ }^{\circ} \mathrm{C}$ over night. The sheets washed in buffer $\mathrm{G}$ with two changes during 20 min were incubated with second antibody solution containing $0.1 \%$ peroxidase conjugated IgG fraction goat anti-rabbit IgG (Cappel) in buffer $\mathrm{G}$, and washed in buffer $\mathrm{G}$ with two changes during $20 \mathrm{~min}$. They were incubated with development solution. The enzymatic reaction was stopped by washing with excess water.

\section{RESULTS}

\section{Detection and purification of cap proteins}

The SDS-PAGE patterns of soluble proteins in crude extracts of the mycelia, caps and stipes of fruit bodies are shown in Fig. 1. The banding patterns of the three 


\section{3}

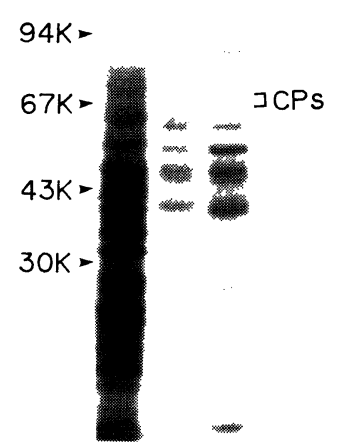

Fig. 1. Total soluble proteins from crude extracts separated by SDS-PAGE. Crude extracts were prepared from mycelia (lane 1), caps (lane 2) and stipes (lane 3) of the dikaryotic strain. A bracket shows the cap proteins. Arrow heads indicate the positions of the following molecular weight standards: phosphorylase b $(94 \mathrm{~K})$, bovine serum albumin $(67 \mathrm{~K})$, ovalbumin $(43 \mathrm{~K})$ and carbonic anhydrase $(30 \mathrm{~K})$.

samples were essentially similar, but there were a few differences among their spectra; for example, the protein band of 40,000 daltons was conspicuous in stipes and mycelia but faint in caps. Comparison of the cap banding patterns with the mycelial and stipe patterns revealed one major quantitative difference. This was the closely arranged bands present only in caps. These bands correspond to apparent molecular weights of around 71,000. In this report these prominent proteins in the cap cells are simply designated as cap proteins (CPs).

A crude extract $(73.3 \mathrm{ml})$ prepared from caps $(32.6 \mathrm{~g})$ of $\mathrm{Fis}^{\mathrm{cl}}$ strain was centrifuged at $105,000 \times g$ for $1 \mathrm{hr}$. The supernatant $(73.0 \mathrm{ml})$ obtained was applied to a DEAE-Sephacel column connected directly to a CM-Sepharose CL-6B column, and eluted with a linear gradient of $\mathrm{NaCl}(0-0.5 \mathrm{M})$. The fractions obtained were examined for the presence of cap proteins by SDS-PAGE. The pooled cap protein fraction $(20.5 \mathrm{ml})$ was concentrated by ultrafiltration with Immercible CX-10. The concentrated solution $(0.9 \mathrm{ml})$ was mixed with a half volume of SDS-containing stop solution and heated at $100^{\circ} \mathrm{C}$ for $2 \mathrm{~min}$. The resulting solution was subjected to SDS-PAGE $(30 \mathrm{~cm}$ gel). The gel was cut out and eluted electrophoretically in $10 \mathrm{~mm}$ Tris- $\mathrm{HCl}(\mathrm{pH} 9.0)$. The eluent was used as a sample of purified cap proteins $(1.3 \mathrm{mg}$ in $600 \mu \mathrm{l})$. The SDS-PAGE profile of the final preparation of cap proteins $(4.6 \mu \mathrm{g})$ is shown in Fig. 2. The slab gel obtained after SDS-PAGE as shown in Fig. 2 was dried, and the bands of cap protein were cut out and used individually as cap protein samples. Four protein bands were purified together by a series of purification procedures. 


\section{Physicochemical characterization of cap proteins}

The molecular weights of four cap proteins purified as shown in Fig. 2 were approximately $74,000,72,000,70,000$, and 68,000 (Fig. 2). The proteins were designated as CP74, CP72, CP70, and CP68, respectively.

Isoelectric focusing indicated that the isoelectric point of these cap proteins was approximately 8.0 .

Peptide mapping was used to try to identify structural similarities among these four cap proteins. Cap protein samples $(1-2 \mu \mathrm{g})$ were subjected to SDS-PAGE in the presence of protease. Densitometer tracings for gel slabs are shown in Fig. 3. The four cap proteins produced four identical peptides (peptide 1, 2, 3, and 6) and two distinct peptides (peptide 4 and 5). CP74 and CP72, and CP70 and CP68 are virtually identical in the patterns of peptide maps with a difference in the relative amounts of peptides. These data suggest that the four cap proteins have a common polypeptide structure.

To examine the possibility that the differences among the four cap proteins may be based on the differences in the amount of oligosaccharides, the presence of sugars in these proteins were analyzed. The PAS staining of cap proteins for sugars was positive (data not shown). The protein bands identified by SDS-PAGE were stained by the Con A-peroxidase staining method. Figure 4 shows that all cap proteins are stained positively by this method, indicating that they are high-mannose type glycoproteins. Peptides obtained by digestion of cap proteins with protease were subjected to the Con A-peroxidase staining. All four cap proteins contained two peptides (peptide 2 and 3) which have oligosaccharide chains (an example of CP70 is shown in Fig. 3). The results indicate that the molecular difference among the four cap proteins may not be due to any difference in the oligosaccharide chains.

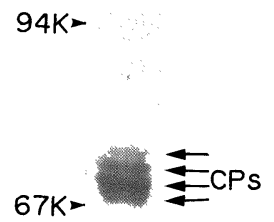

Fig. 2. SDS-PAGE of purified cap proteins. Cap proteins were purified from crude extract prepared from caps of the Fis ${ }^{\text {cl }}$ strain by DEAE-Sephacel and CM-Sepharose CL$6 \mathrm{~B}$ chromatography, and preparative SDS-PAGE $(30 \mathrm{~cm}$ gel). Arrows indicate the positions of cap proteins, and arrow heads indicate the positions of the molecular weight standards (see Fig. 1). 


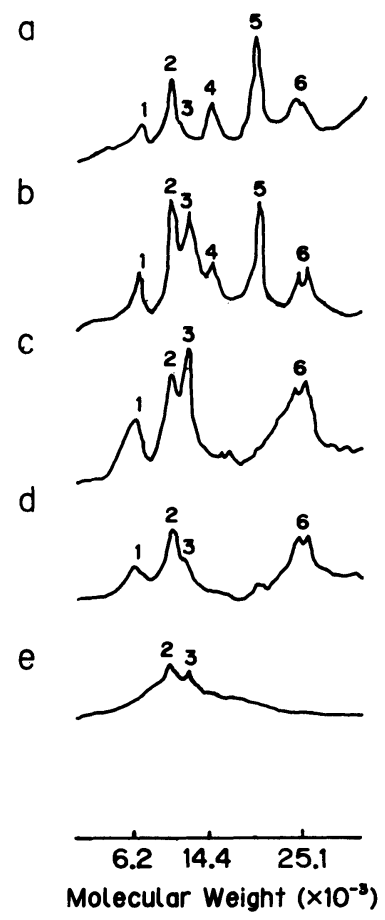

Fig. 3. Densitometric tracings of cap proteins analyzed by SDS-PAGE in the presence of protease. The slab gels were stained for peptides by the silver-staining $(a-d)$ or Con A-peroxidase staining method (e). Photographs of slab gels were scanned with a densitometer (Toyo Digital Densitrol DMU-33C). a, CP74; b, CP72; c and e, CP70; d, CP68.

\section{$67 \mathrm{~K}=\mathrm{UCPS}$}

Fig. 4. Con A-peroxidase staining of cap proteins. A purified cap protein sample $(6 \mu \mathrm{g})$ separated by SDS-PAGE was transferred to a nitrocellulose sheet and stained with the Con A-peroxidase staining method. A bracket shows cap proteins, and an arrow head indicates the position of the molecular weight standard (bovine serum albumin). 


\section{5}

Fig. 5. Immunological detection of cap proteins. Supernatant fractions obtained from mycelia and fruit bodies were subjected to SDS-PAGE and immunoblotting. Lanes $1-6$, Fis ${ }^{\mathrm{cl}}$; lanes 7-13, dikaryon. Lanes 1-3 and 7-9, mycelium; lanes 4 and 10, young primordia; lanes 5 and 11, stipes; lanes 6 and 12, caps; lanes 13-15, samples of cap proteins $(13,4.6 \mu \mathrm{g} ; 14,2.3 \mu \mathrm{g} ; 15,1.2 \mu \mathrm{g})$. A bracket shows cap proteins, and an arrow head indicates the position of the molecular weight standard (bovine serum albumin).

Table 1. Relative levels of cap proteins in mycelia and fruit bodies.

\begin{tabular}{|c|c|c|c|c|}
\hline \multirow{2}{*}{$\begin{array}{c}\text { Source } \\
\text { (height of fruit bodies in } \mathrm{mm} \text { ) }\end{array}$} & \multicolumn{2}{|c|}{$\begin{array}{l}\text { Culture time } \\
\quad \text { (days) }\end{array}$} & \multicolumn{2}{|c|}{$\begin{array}{l}\text { Relative level of } \\
\text { cap proteins }(\%)^{a}\end{array}$} \\
\hline & $\mathrm{Fis}^{\mathrm{el}}$ & Dikaryon & $\mathrm{Fis}^{\mathrm{cl}}$ & Dikaryon \\
\hline Cap $(36-38)^{b}$ & 8 & 9 & 100 & 100 \\
\hline Stipe $(36-38)^{b}$ & 8 & 9 & $<0.3$ & $<0.3$ \\
\hline Cap $(30-36)$ & 8 & - & $<0.3$ & - \\
\hline Stipe $(30-36)$ & 8 & - & $<0.3$ & - \\
\hline Cap $(20-22)$ & 8 & - & $<0.3$ & - \\
\hline Stipe $(20-22)$ & 8 & - & $<0.3$ & - \\
\hline Cap (13-15) & 8 & - & $<0.3$ & - \\
\hline Stipe $(13-15)$ & 8 & - & $<0.3$ & - \\
\hline Upper part of primordium (5-9) & 8 & 8 & $<0.3$ & $<0.3$ \\
\hline Lower part of primordium (5-9) & 8 & 8 & $<0.3$ & $<0.3$ \\
\hline Young primordium $(0.5-2)$ & 6 & 6 & $<0.3$ & $<0.3$ \\
\hline Upper part of dark stipe ${ }^{c}$ & 12 & - & $<0.3$ & - \\
\hline Lower part of dark stipe ${ }^{c}$ & 12 & - & $<0.3$ & - \\
\hline Mycelium & 9 & 9 & 2 & $<0.3$ \\
\hline Mycelium & 6 & 6 & 1 & $<0.3$ \\
\hline Mycelium & 5 & 3 & 1 & $<0.3$ \\
\hline
\end{tabular}

a Photographs of blotted nitrocellulose sheets were scanned with a densitometer (Toyo Digital Densitrol DMU-33C), and the heights of peaks on the charts were measured in comparison with those for the standard samples of purified cap proteins. The values obtained were normalized according to the amount of total protein (mg). The level obtained for matured caps were assigned a value of $100 \%$.

$b$ The fruit bodies at this stage were mature and the caps were opening.

c Dark stipes are malformed fruit bodies obtained by incubating cultures in continuous dark. 
Immunological detection of cap proteins

Purified preparations of cap proteins were used to generate specific antibodies, and crude extracts prepared from mycelia, hyphal knots, fruit body primordia, stipes and caps were analyzed by immunoblotting using these antibodies (Fig. 5). Photographs of the blotted sheets were scanned in the gel region corresponding to the bands of cap proteins, and the relative levels of the proteins were calculated with the levels of cap proteins found in caps as standard. Table 1 summarizes the relative levels of cap proteins of various sources. Stipes of fruit bodies had very low levels. Young primordia and the apical and basal parts of primordia of fruit bodies harvested before stipe elongation had no detectable levels of cap proteins. The proteins were synthesized during maturation of the fruit bodies. Young and old mycelia of $\mathrm{Fis}^{\mathrm{cl}}$ had less than $2 \%$ of cap proteins found in cap cells. The apical and basal regions of the dark stipes which are malformed fruit bodies formed under continuous dark condition developed rudimentary caps and produced no cap proteins. Caps of dikaryotic fruit bodies produced approximately the same level of cap proteins as in caps of $\mathrm{Fis}^{\mathrm{cl}}$, but the stipes, fruit body primordia and mycelia of the dikaryotic strain produced no detectable cap proteins.

\section{DISCUSSION}

From the evidence presented here, it appears that four specific proteins are produced in the maturing caps of fruit bodies. Since the stipes directly connected with the caps and mycelia had very low levels of these proteins, these proteins could be termed characteristically cap-specific. The primordia of fruit bodies harvested prior to elongation of stipes produced no detectable levels of cap proteins. Therefore, it is postulated that these proteins are produced during the maturation of the caps.

Four cap proteins detected here were purified together, had similar molecular weights and an isoelectric point, and showed similar characteristics of glycoproteins. There is a possibility that these proteins are derivatives of a common polypeptide. However, cap proteins may not be degradation products of a large protein, since no protein of higher molecular weight than 74,000 daltons was detected by immunoblotting through all of the developmental stages examined.

The functions of these cap proteins is unknown. It is known that in C. lagopus and $C$. cinereus significant amounts of several enzymes such as NADP-dependent glutamate dehydrogenase, chitinase and glucanase were produced in cap cells of fruit bodies at the early stage of development of caps, but an extremely small amount of these enzymes were produced in stipe cells $(6)$. The timing of production of the cap proteins observed here is similar to that of the enzymes examined previously(6). These results suggest the existence of a common mechanism for regulating both cellular events leading to the maturation of fruit bodies and sequential production of these proteins and enzymes.

The levels of cap proteins were measured efficiently by the immunoblotting 
method and changes in the amounts of specific proteins appeared in the various cells of this fungus. Thus, the antisera against cap proteins may be used as one of the probes to investigate the process of cap differentiation.

We thank Dr. S. Nomura, Messrs. S. Tomioka, and K. Shimogawara for technical comments on purification of cap proteins, Drs. H. Yamaki, K. Takada, M. Honma and Mr. H. Sasaki for the immunological studies, and Dr. S. Sato for the PAS and Con A-peroxidase staining.

\section{REFERENCES}

l) D. MoOre, Exp. Mycol., 8, 283 (1984).

2) G. R. Stewart and D. Moore, J. Gen. Microbiol., 83, 73 (1974).

3) A. Al-Gharawi and D. Moore, Biochim. Biophys. Acta, 496, 95 (1977).

4) J. O. Ewaze, D. Moore, and G. R. Stewart, J. Gen. Microbiol., 107, 343 (1978).

5) D. MoOre, Biochim. Biophy's. Acta, 661, 247 (1981).

6) H. Miyake, T. Takemaru, and T. Ishikawa, Arch. Microbiol., 126, 201 (1980).

7) K. Komagata and M. Okunishi, J. Gen. Appl. Microbiol., 15, 231 (1969).

8) I. Uno and T. IshiKawa, Mol. Gen. Genet., 113, 228 (1971).

9) H. Miyake, K. Tanaka, and T. Ishikawa, Arch. Microbiol., 126, 207 (1980).

10) U. K. Laemmli, Nature, 227, 680 (1970).

11) D. W. Cleveland, S. G. Fischer, M. W. Kirschner, and U. K. Laemmli, J. Biol. Chem., 252, 1102 (1977).

12) G. Konat, H. Offner, and J. Mellah, Experientia, 40, 303 (1984).

13) J. G. Howe and J. W. B. Hershey, J. Biol. Chem., 256, 12836 (1981).

14) S. Kijimoto-Ochiai, Y. U. Katagiri, and H. Ochial, Anal. Biochem., 147, 222 (1985). 